\title{
Irena Górska Biografia sztuki literackiej.
Próba rekonstrukcji projektu literackiego
Tadeusza Kantora
}

ABSTRACT. Górska Irena, Biografia sztuki literackiej. Próba rekonstrukcji projektu literackiego Tadeusza Kantora [Biography of literary art. An attempt at a literary project of Tadeusz Kantor]. „Przestrzenie Teorii" 12. Poznań 2009, Adam Mickiewicz University Press, pp. 57-73. ISBN 97883-232-2077-0. ISSN 1644-6763.

In universal consciousness, Tadeusz Kantor is an artist of theatre, painter, creator in other fine arts, but also author of a great number of writings on aesthetics, manifestos, sketches, essays, notes from rehearsals, dramatic scores and of some poems. What is characteristic is that various forms of writing, which by assumption are a theoretical expression of Kantor's ideas on theatre or fine arts, at the same time obtain a character of a literary work while his verses direct one towards theory.

Painting, theatre and ideas connected with them are supplemented in the act of writing, which becomes a necessity for Kantor. The author of Dead Class changes the theatrical project into a literary project and in his writing he intermingles drama, commentary, theatre, his own theoretical and biographical reflections, observations of a masterpiece and states of his own consciousness. He plays theatrical ideas not only on the stage but also in theoretical texts and in verses. It is just in writing that the artist from Wielopole establishes anew the relations between theatre, literature and his own biography.

Należy działać w całości sztuki ${ }^{1}$.

Tadeusz Kantor w powszechnej świadomości to artysta teatru, malarz, plastyk, twórca ambalaży. Poglądy artysty na sztukę teatralną i plastykę możemy zrekonstruować przede wszystkim, opierając się na licznych tekstach teoretycznych. Jest przecież twórca Umarłej klasy autorem ogromnej liczby pism estetycznych, manifestów, szkiców, esejów, zapisków z prób, partytur dramatycznych, ale też kilku wierszy, a mimo to rzadko chyba myślimy o Kantorze jako o pisarzu. Komentowanie własnej twórczości teatralnej i plastycznej w tej rozmaitości uprawianych form pisarskich zyskuje literacki charakter.

Projektując teatr czy malarstwo, pisze Kantor - by sparafrazować Różewicza - biografię dzieła literackiego. $\mathrm{Z}$ idei teatralnych rodzi się po prostu literatura.

1 T. Kantor, Metamorfozy: teksty o latach 1934-1974, t. 1, wybór i opracowanie K. Pleśniarowicz, Kraków 2005, s. 19. 
Warto zatem zobaczyć artystę z Wielopola jako pisarza, który nie tylko pisze wiersze, ale nawet pisma teoretyczne w wiersze zamienia ${ }^{2}$. Czyni tak wbrew wyznaniu: „Ja pod słowem »sztuka« rozumiem malarstwo i teatr. Nie mogę nic mówić na temat literatury i innych dziedzin, bo to nie są moje specjalności”’ Jednak to właśnie literatura, staje się jedną ze „specjalności” Kantora.

Pisarstwo twórcy Umartej klasy ma konstrukcję chiazmu4: wiersze wyraźnie odsyłają do teorii, teksty teoretyczne, zamieniając się w wiersze, wiodą ku literaturze. Chiazm prowadzi na obszar nierozstrzygalności, bo zależnie od kontekstu, a niezależnie od intencji artysty, większość pism Kantora daje się czytać jako literatura bądź jako teoretyczny komentarz.

\section{Wiersze, czyli projektowanie teatru}

„Oczywiście nigdy nie piszę wierszy, ponieważ mam świadomość, że byłbym grafomanem" 5 - wyznaje artysta. Wbrew tej deklaracji Kantor wiersze pisał. Przecież formę wierszową przyjmuje mnóstwo jego pism teoretycznych: szkiców, manifestów, notatek, esejów itp. Jest też jednak Kantor autorem tekstów z założenia literackich. Utwory: POCIĄG/ TEKST/ROZMOWY/czas, A'laube, Ksiadz Józef to teksty „autonomiczne", czyli takie, których nie można połączyć z żadnym wydarzeniem $\mathrm{w}$ artystycznej biografii autora Wielopole, Wielopole 6 . Co istotne, niektóre pod względem treści i formy przypominają manifesty, szkice czy eseje teoretyczne zatem są utworami literackimi po prostu z autorskiego nadania, ale umieszczone i czytane w kontekście tekstów teoretycznych właściwie się od nich nie różnią. Fakt ten bynajmniej nie ujmuje im nic $\mathrm{z}$ ich poetyckiej jednak natury, bo i pisma teoretyczne Kantora nierzadko przecież zamieniają się w poezję?.

${ }^{2}$ Fakt, że Kantor teoretyk to w pewnym stopniu również Kantor poeta sygnalizuje w swej książce Agata Stankowska. Zob. taż, Poezji nie pisze się bezkarnie. Z teorii i historii tropu poetyckiego, Poznań 2007, s. 194.

${ }^{3}$ K. Miklaszewski, Tadeusz Kantor. Między śmietnikiem a wiecznościa, Warszawa 2007 , s. 33.

${ }^{4} \mathrm{Na}$ temat chiazmu zob. P. de Man, Ideologia estetyczna, przeł. A. Przybysławski, Wstęp napisał A. Warmiński, Gdańsk 2000, s. 88 i n.

5 T. Kantor, Teatr Śmierci. Teksty z lat 1975-1984, wybór i opracowanie K. Pleśniarowicz, t. 2, Kraków 2004, s. 465.

6 Zob. na ten temat: P. Stangret, Trzy teksty Tadeusza Kantora, „Teksty Drugie” 2005, nr 6.

${ }^{7}$ Por. D. Ulicka, Teoria „w” literaturze, [w:] taż, Literaturoznawcze dyskursy możliwe. Studia $z$ dziejów nowoczesnej teorii literatury w Europie Środkowo-Wschodniej, Kraków 2007. 
Tytuł jednego z wierszy autora Umartej klasy POCIACG/TEKST/ ROZMOWY/czas zwraca uwagę już ze względu na swój wizualny charakter. Zaciekawiać może zapis wielkimi literami trzech pierwszych słów i małymi ostatniego wyrazu w tytule - słowa czas. Istotne też wydaje się oddzielenie poszczególnych wyrazów-haseł ukośnikami. Tytuł ten z pewnością nie jest poetycki. Każe myśleć raczej o manifeście, może jakiejś brulionowej notatce, teoretycznym komentarzu do spektaklu, jakie Kantor zwykł pisać. Nie zapowiada poezji, ale intryguje i formą zapisu, i „hasłową" formułą tytułu. Już po lekturze pierwszych słów wiemy, że jesteśmy w teatrze, bo oto:

przez widownię ,jadą” wagony jakiegoś pociągu - poprzez otwory -

bowiem pociąg jest ciężarowy, taki jakim wozi się bydło - z boku ściany się rozsuwają ${ }^{8}$

W tych bydlęcych wagonach ${ }^{9}$ jadą nieokreśleni ludzie, zawieszeni w próżni, którzy mają cel, których czeka las. Nie muszą oni chodzić po ziemi, sa bowiem $w$ innym wymiarze i $w$ innej rzeczywistości.

Natomiast ci, którzy obserwują jadący pociąg, stoja i patrza, sq na ziemi, maja swoje sprawy / sq w innej kondycji / moralnej / codziennej / nieciekawej.

I tu kończy się pierwszy obraz - śnionego - jak się dowiadujemy spektaklu. Następnie pojawia się zapowiedź drugiego obrazu:

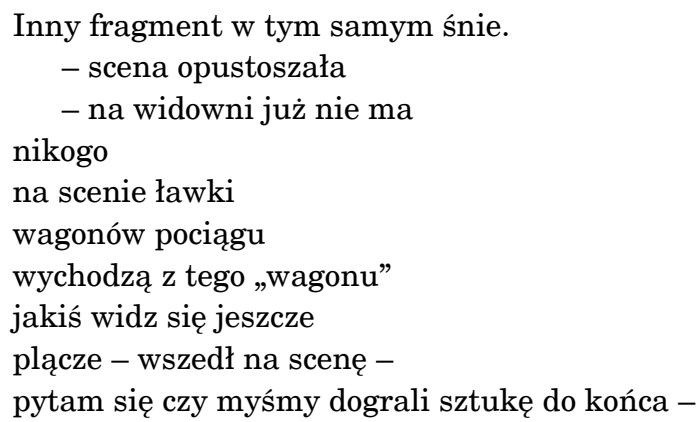

Zatem wiersz okazuje się zapisem snu. Rozpada się wyraźnie na 2 części, z których pierwsza opisuje przebieg spektaklu, druga mówi o tym, co dzieje się po nim. Uczestnicy seansu po jego zakończeniu:

8 T. Kantor, POCIACG/TEKST/ROZMOWY/czas, „Teksty Drugie” 2005, nr 6. Opuszczenie w cytowanym fragmencie moje - I.G. Kolejne fragmenty tego utworu cytuję wg tego samego źródła.

9 Nieodparcie nasuwa się tu skojarzenie z twórczością Tadeusza Różewicza, który wielokrotnie przywołuje w swej twórczości motyw bydlęcych wagonów. 


$$
\begin{aligned}
& \text { - wychodzą z wagonu } \\
& \text { idą do garderoby } \\
& \text { tak jak zawsze po } \\
& \text { skończonym spektaklu. } \\
& \text { - Aktorzy już wyszli } \\
& \text { rozszminkowali się } \\
& \text { zdjęli kostiumy } \\
& \text { i poszli do domów - }
\end{aligned}
$$

Można powiedzieć, że to wiersz teatralny, który nieodparcie odsyła ku tekstom teoretycznym autora Umarłej klasy. Właściwie wydaje się, że niewiele go różni od takiego np. tekstu ze zbioru pism teoretycznych:

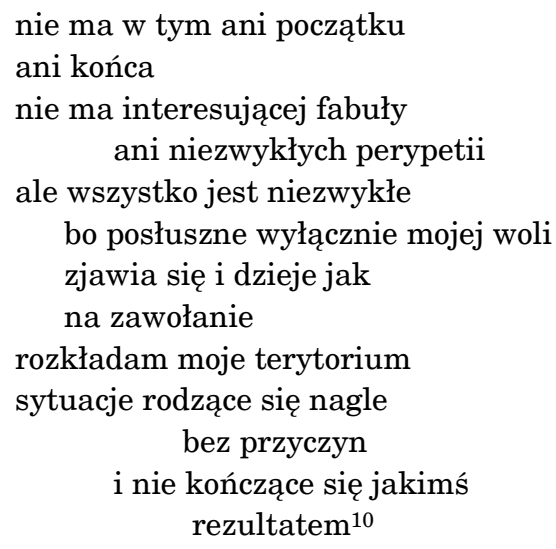

Może nawet przytoczone Wyjattki z eseju „Miejsce dokładne” są bardziej poetyckie niż z założenia literacki utwór POCIĄG/TEKST/ROZMOWY/czas?

A'laube to również wiersz odsyłający do teatru. Wyrażone tu dwukrotnie pragnienie uchwycenia ulotnej chwili przed świtem, która / jest wattym przedtużeniem snu, opatrzone zostaje taką oto teatralną dygresją: pokazać to $w$ akcji / to przedtużenie / $i$ to, że watte / - czepiajace się / jakiejś tamtej rzeczywistości ${ }^{11}$. Zatem $\mathrm{w}$ tym kontekście wiersz ten można czytać jako swoisty projekt spektaklu, zapis pomysłu na to, co ma być pokazane na scenie, $w$ akcji. Znajdziemy tu też sugestie podobne do tych z niektórych manifestów, by dzieło pozostawało niegotowe, niedopracowane:

$$
\begin{aligned}
& \text { przechodzić nagle } \\
& \text { na inne pola - } \\
& \text { inne tematy - }
\end{aligned}
$$

10 T. Kantor, Teatr Śmierci..., dz. cyt., s. 335.

11 Tegoż, A’laube, „Teksty Drugie” 2005, nr 6, s. 210.

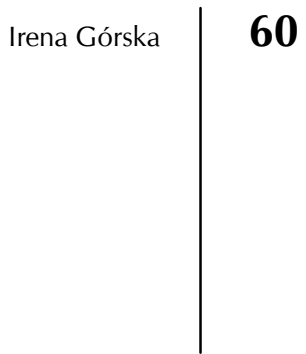




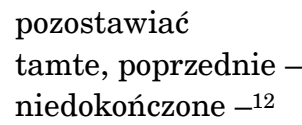

W kontekście omówionych wierszy najciekawsze wydają się te obserwacje, które odsyłają do myślenia o teatrze, ale przywołują też problematykę obecną w pismach teoretycznych (niekoniecznie teatralną). Teksty z założenia literackie odsyłają tu bowiem poza obszar literatury.

Spośród trzech wierszy Kantora jedynie Ksiądz Józef wydaje się najbardziej „poetycki”, daleki w swym charakterze od manifestów, zapisków teoretycznych. Nie ma w nim nawet odniesień do teatru, chyba że w samej postaci tytułowej widzieć księdza Śmietanę z Wielopola, Wielopola ${ }^{13}$.

\section{Teksty teoretyczne, czyli projektowanie literatury}

Teksty literackie Kantora odsyłają zatem ku teorii, ku teatrowi, ale dzieje się też odwrotnie - zarówno idee teoretyczne, jak i sam teatr, wiodą ku literaturze.

W kontekście rozważań o literackich poczynaniach twórcy Umartej klasy szczególnie interesujący wydaje się teoretyczny przecież fragment O poezji z tomu Dalej już nic. Na uwage zasługuje on co najmniej z dwóch powodów. Po pierwsze - ze względu na znamienny tytuł i związaną z nim deklarację zawartą w pierwszym wersie (Nie "uprawiam” poezji), po drugie - i najważniejsze - ze względu na fakt, że wyznanie o nieuprawianiu poezji zamienia się w poezję właśnie:

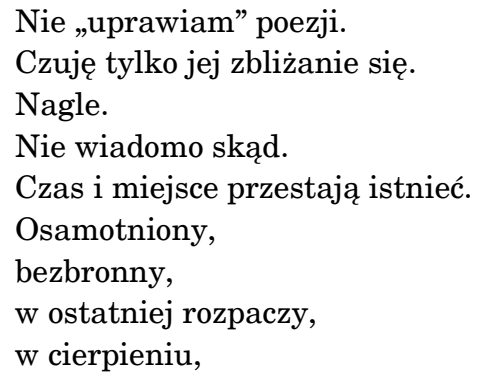

12 Tamże, s. 211

${ }^{13}$ Na podobieństwo tych postaci zwraca uwagę Paweł Stangret. Zob. tegoż, Trzy teksty Tadeusza Kantora, „Teksty Drugie” 2005, nr 6, s. 219. Warto zauważyć, że w edycji pism opracowanej przez K. Pleśniarowicza tekst ten został włączony do rozdziału pt: Spotkania ze śmiercia. Pod zapisem tytułu wiersza znalazł się tytuł spektaklu Wielopole, Wielopole. Zob. T. Kantor, Dalej już nic. Teksty z lat 1985-1990, t. 3, wybór i opracowanie K. Pleśniarowicz, Kraków 2005, s. 221-222. 


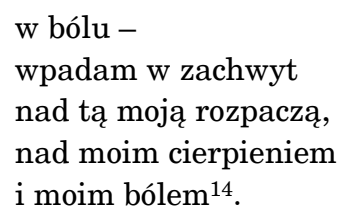

Zawarte we wstępie przytoczonego fragmentu wyznanie może zmylić czytelnika. Nie pozwala ono zaufać artyście. Poezja pojawia się tu nie wiadomo skad. Co istotne, równie znienacka nadchodzi, gdy mowa o malarstwie. Tekst zatytułowany właśnie tak: $O$ malarstwie również - choć z założenia teoretyczny - ma formę poetycką. To swoisty poemat o miłości do teatru i malarstwa, o ciągłym zaczynaniu na nowo i nieustannym wracaniu do źródeł inspiracji, do młodości. Najistotniejsza deklaracja znajduje się tu jednak w zakończeniu: Zapewniam: cały czas mówiłem o malarstwie ${ }^{15}$. Można by dodać: ale mówiłem językiem poezji. Wydaje się, że dwuznaczność tego stwierdzenia wynika z wątpliwości, jak mówić o malarstwie, skoro nie można jego własnym językiem. Twórca te wątpliwości rozwiewa:

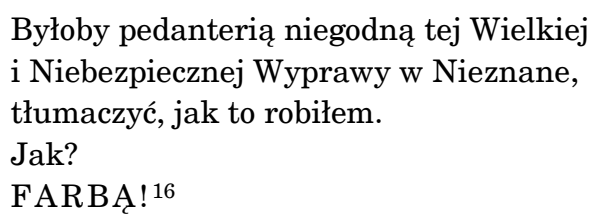

Dość to przewrotne zapewnienie. Okazuje się, że mówić o malarstwie można tylko językiem poezji.

Związki między teorią a literaturą dają się widzieć w dwóch porządkach, choć - co warto podkreślić - cały czas odnoszą się do jednego działania, czyli tworzenia projektu literackiego z idei teatralnych.

Porządek pierwszy nazwać można porządkiem języka, mowy, drugi porządkiem świadomości. Teksty teoretyczne niejednokrotnie zamieniają się w teksty literackie i to oczywiście dzieje się na płaszczyźnie językowej, ale sam fakt zapisywania, komentowania idei teatralnych wyrasta z wewnętrznej potrzeby opisu własnej działalności artystycznej. Sam akt pisania staje się dla artysty koniecznością:

14 T. Kantor, Dalej już nic..., dz. cyt., s. 217.

15 Tamże, s. 220.

16 Tamże. 
Odczuwam jakąs konieczność pisania o tym, co robie, co maluje, rysuję. Czasami nawet wydaje mi się, że to, co napiszę jaśniej określi myśl, ideę, treść. Pragnę uchwycić tego przyczynę ${ }^{17}$. Kantor wyznaje, że w działaniach plastycznych, jak malarstwo czy rysunek przeważają: intuicja, instynkt, żywioł, podświadomość, to pisanie o tym sprawia, że wszystko staje się świadomością. Pisanie wiedzie zatem ku powierzchni, wydobywa na jaw to, co zawikłane, ciemne, sprawia, że ukryte, staje się jawne, rozumowe ${ }^{18}$.

Zatem malarstwo, teatr i związane $\mathrm{z}$ nimi idee znajdują dopełnienie w akcie pisania. Akt ten czyni je jasnymi, umożliwia ich poznanie, dookreśla. Można powiedzieć więcej - to pisarstwo staje się obszarem, na którym dokonuje się obserwacji własnej świadomości twórczej, tu w pełni zostają wyrażone pierwotne myśli i idee, tu wreszcie zostaje ujarzmione to, co instynktowne i żywiołowe. Pisanie wprowadza ład, porządkuje, prowadzi do artystycznego samopoznania.

Twórca Umartej klasy zadaje pytanie:

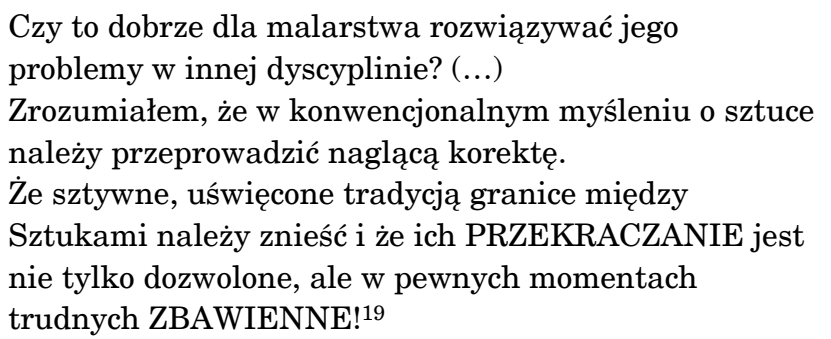

Znoszenie granic pomiędzy sztukami, którego dokonuje autor Wielopola, Wielopola, pozwala przez pryzmat tekstów teoretycznych zobaczyć Kantora jako pisarza, który pokazuje, jak w obszarze teatru i plastyki rodzi się projekt literacki. O ile bowiem u Różewicza opisanie dramaturgii prowadzi do dekonstrukcji literatury, o tyle u Kantora opisywanie idei teatralnych zamienia się w literaturę.

Na stykach, pograniczach, marginesach, w obszarach „pomiędzy” pomiędzy malarstwem a teatrem, teatrem a pisaniem, pisaniem a własną biografią artysty rozgrywa się sztuka totalna, za Lechem Stangretem można powtórzyć, że powstaje ambalaż totalnego dzieła i to nie tylko ambalaż malarski ${ }^{20}$. Teatr projektuje tu literaturę. Taki sposób postępowania - dopełnianie komentarzem literackim plastyki i teatru przypo-

17 T. Kantor, Metamorfozy..., dz. cyt., s. 8.

18 Tamże.

19 Tamże, s. 18-19, opuszczenia w cytowanym fragmencie moje - I.G.

${ }^{20}$ L. Stangret, Tadeusz Kantor. Malarski ambalaż totalnego dzieła, Kraków 2006. 
mina technikę ambalażu To pisarstwo jest domknięciem, opakowaniem całości sztuki.

Raz są to zwyczajne notatki po prostu takie, jakie się robi, aby nie zapomnieć, innym razem rodzaj komentarzy, jakbym chciał upewnić się, o słuszności czegoś, co jest nieuchwytne, przetłumaczyć na inny jeszcze ,język”, jakbym szukał „etymologii” obrazu.

Kiedy indziej idea wydaje mi się tak niemożliwa i ważna równocześnie, że konieczny staje się manifest.

Czasami piszę niemal „partyturę” obrazu.

Nie ma co ukrywać - po prostu jest we mnie potrzeba „opisu” malarstwa, co przez poważnych ekspertów uznawane jest raczej za naiwność.

Osobiście, moją namiętność malarstwa odczuwam

Jako pierwotną

I wrodzoną.

Z drugiej strony mam niejaką nieufność do profesjonalnego zamykania się $\mathrm{w}$ polu jednego gatunku.

Rezultatem tego wszystkiego

są eseje i teksty

różnego rodzaju:

poetyckie,

szydercze,

bluźniercze,

redukujące wszelką wzniosłość, patos i powszechny dziś

pretensjonalny scjentyzm

do codzienności,

do realności niskiej rangi

do BIEDY

i śmieszności ${ }^{21}$.

Ten dość obszerny cytat wydaje się tu zasadny z dwóch co najmniej powodów. Po pierwsze wyjaśnia przede wszystkim, z czego wynika potrzeba pisania o sztuce, dokonywania owego przekładu na inny język i chociaż mowa tu o malarstwie, to wypowiedź tę można też odnieść do teatru, bo przecież teatr i malarstwo to dla Kantora jedność. W jego przedstawieniach obecna jest optyka malarska, przejawiajaca sie $w$ konstruowaniu spektaklu $z$ obsesyjnie powracajacych obrazów, $w$ malarstwie uderza teatralizacja autoportret ${ }^{22}$. Po drugie - i chyba dla tych rozwa-

21 T. Kantor, Metamorfozy..., dz. cyt., s. 7-8.

22 M. Żółkoś, „Dom oniryczny” $w$ autoportretach $i$ ostatnich spektaklach Tadeusza Kantora, [w:] Dialog w dramacie, red. W. Baluch, L. Czartoryska-Górska, M. Żółkoś, Kraków 2004, s. 283. O wprowadzaniu fikcji obrazu w realność sceny pisze też M. Pieniążek: Akt twórczy jako mimesis. „Dziś sq̨ moje urodziny” - ostatni spektakl Tadeusza Kantora, Kraków 2005, s. 160-161. 
żań najważniejsze - zacytowany fragment wypowiedzi Kantora również demonstruje, jak ta potrzeba opisywania malarstwa, poszukiwania etymologii obrazu czy pisania jego partytury zamienia się w literaturę, jak płynnie z komentarza wyłania się wiersz. Komentarz mówi o sztuce i jednocześnie demonstruje swą przemianę w literaturę. Kantorowski projekt literacki ujawnia się tu w chwili, gdy ciągle jeszcze jest właśnie dosłownie projektem, formą niedomkniętą, surową, ale też właśnie dlatego - w myśl idei Kantora - powinien być uznany za gotowe dzieło. Przytoczony fragment, mówiąc o sztuce, unaocznia własne stawanie się literaturą. Na tym etapie zaczyna się rodzaj performatywnej gry pomiędzy jednoczesnym komentowaniem i demonstrowaniem reguł. Kantor, mówiąc, że jest w nim potrzeba opisu, jednocześnie performatywnie ją realizuje.

\section{Pisanie na próbę}

Przywołana uprzednio figura chiazmu określa relacje pomiędzy tym, co literackie, a tym, co teoretyczne. Okazuje się bowiem, że wiersz można czytać po prostu jako wiersz, ale też jako komentarz (niezależnie od tego, jaka była intencja twórcy). Idąc tropem figur słów, można również pisarstwo, jakie uprawia Kantor, ujmować w kategoriach korekcji.

Ta zaś odsyła do takich określeń, jak próba, niegotowość, wariantywność. W tym obszarze umieścić należy wszystko to, co niegotowe, surowe, pisane „na brudno”, będące zapisem pomysłu, wersją itp. ${ }^{23}$. Pisarstwo Kantora można w ogóle określić jako pisanie „na próbę”. Wydaje się to tym bardziej trafne, że sam artysta postuluje, by za twórczość uznać nie „gotowe” dzieło sztuki, ale m.in.:

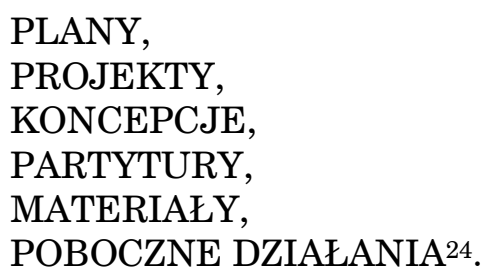

Ważniejsze od finalnego dzieła są próby i wprawki, przygotowania do realizacji obrazu czy spektaklu, ćwiczenia, które same stają się celem

23 Trafne wydaje się też mówienie o sylwiczności bądź fragmentaryczności tych form. Zob. R. Nycz, Sylwy wspótczesne, Kraków 1996. O różnych rozumieniach fragmentu pisze K. Bartoszyński, O fragmencie, [w:] Między tekstami, red. J. Ziomek, Warszawa 1992, s. 67.

24 T. Kantor, Metamorfozy..., dz. cyt., s. 20. 
ostatecznym, tworzą całość dającą się widzieć „jako rewizja tego, co zostało za każdym razem osiągnięte"25.

Dlatego zapewne swe teksty określa artysta mianem etiud, szkiców i wielokrotnie rozpisuje sceny swoich spektakli. W ten sposób ukazuje ciągłą niegotowość swego dzieła, ustala wciąż na nowo ostateczny kształt tekstu (?), spektaklu (?), prowadzi też grę z odbiorcą, obnażając tajniki własnego warsztatu artystycznego i związane z tym stany swojego umysłu.

Autor Umarłej klasy zauważa, że Czynność pisania ksiażki, komponowania symfonii, malowania obrazu jest uznana za proces kreacji. (...) Konsumuje się jedynie produkt $w$ formie ksiazki, utworu wykonanego przez orkiestre, wystawionego obrazu ${ }^{26}$. Zatem jako dzieło funkcjonuje to, co jest śladem procesu twórczego. Wszystko, co ten końcowy efekt poprzedza, jest skrzętnie przed odbiorcą skrywane. Zdaniem Kantora właśnie to, co niewygładzone, niewyszlifowane $i$ niereprezentatywne stanowi oryginalna, pierwotna materie tworzenia ${ }^{27}$.

Dlatego za twórczość uznaje artysta rejony „strychów” świadomości, składów pamięci, nobilitowanie tego, co nazywa się rupieciarnia naszej świadomej działalności 28 . Z tych właśnie strychów, składów, rupieciarni rodzą się zasadnicze dla Kantora formy pisarskie, które jednak ciągle w powszechnej świadomości uznawane są raczej za poboczne, marginalne, traktowane jako półprodukt, przygotowanie do finalnego dzieła. $\mathrm{U}$ autora Umartej klasy ten margines staje się centrum.

Zatem to wszystko, co niskie, wstydliwe, bardzo osobiste, nim jeszcze zostanie wygładzone, dopracowane, zostaje wyniesione do rangi dzieła sztuki ${ }^{29}$. Takie myślenie Kantora szczególnie uprawomocnia czytanie jego tekstów teoretycznych jako dzieła artystycznego, literackiego. Wydaje się to tym bardziej słuszne, że granice pomiędzy tym, co literackie i nieliterackie, już dawno zostały rozmyte.

Można powiedzieć, że nobilitowania tego, co nieartystyczne dokonuje sam Kantor, gdy do rangi finalnego dzieła (z założenia teoretycznego) wynosi często teksty niewykończone, surowe, brudnopisowe, o charakterze spontanicznie robionych notatek, a co ważniejsze, tym postępowaniem uprawomocnia wyniesienie własnych tekstów-komentarzy do rangi dzieła literackiego, gdyż te robocze zapiski często po prostu zamieniają się $\mathrm{w}$ wiersze. Takie postępowanie dowodzi, że tradycyjne rozróżnienia między tekstem komentowanym i komentującym nie dają się już utrzymaćc ${ }^{30}$.

${ }^{25}$ R. Bubner, Doświadczenie estetyczne, przeł. K. Krzemieniowa, Warszawa 2005, s. 75.

${ }_{26}^{26}$ T. Kantor, Teatr Śmierci..., dz. cyt., s. 347.

27 Tamże.

28 Tamże.

${ }^{29}$ Zob. T. Kantor, Metamorfozy..., dz. cyt., s. 225.

${ }^{30}$ Por. M.P. Markowski, Efekt inskrypcji. Jacques Derrida i literatura, Kraków 2003, s. 337 . 
Należy podkreślić, że dzieło pisane przez Kantora ma charakter szczególny nie tylko dlatego, że teoria i literatura nieustannie się w nim przenikają, ale też dlatego, że często opisywanie własnych idei artystycznych jest jednoczesnym demonstrowaniem, unaocznianiem procesu twórczego ${ }^{31}$, a nawet stanów świadomości artysty. Trafnym przykładem ilustrującym te kwestie wydają się przede wszystkim notatki z prób. Niektóre z nich mają charakter scenariusza, są po prostu opisem przebiegu danej sekwencji, ale często poszczególne sceny w danym spektaklu mają swoje warianty, a w nich pojawiają się odautorskie dygresje. Ten ich roboczy, dygresyjny charakter nie przeszkadza, by niejednokrotnie zamieniały się one $\mathrm{w}$ wiersz. Zapisy z prób są nie tylko refleksją nad spektaklem, odsłonięciem poszczególnych etapów pracy, ale ujawniają też rozterki i wątpliwości twórcy, stanowią rodzaj analiz własnych procesów myślowych.

Od autorskiej refleksji nad przebiegiem prób spektaklu, jak np. w notatkach z prób Wielopola, Wielopola:

Scena ta zaaranżowana 13.03 i 14.03 - ulega przemianom (Wielopole, Wielopole, scena „Adaś odjeżdża na front”, próba z 28.03.1980, Teatr Śmierci, s. 301).

Tak wyglądała ta ostatnia sekwencja na poprzedniej próbie. Obecnie uległa zdecydowanej zmianie (Wielopole, Wielopole, scena „Adaś odjeżdża na front”, próba z 28.03.1980, Teatr Śmierci, s. 302).

prowadzi nas artysta do refleksji na temat własnej świadomości.

Poprzednia wersja „Ostatniej Wieczerzy” po ponownym przejrzeniu wydaje mi się zbyt jednowarstwowa, płaska. Konieczne są zmiany (...) (Wielopole, Wielopole, scena „Ostatnia Wieczerza”, próba z 02.04.1980, Teatr Śmierci, s. 309).

Oczywiście jak zawsze nic na początku nie wiem. Potem coś zaczyna się klecić, i nagle bardzo szybko rodzi się pomysł... (Wielopole, Wielopole, scena „Ostatnia Wieczerza”, próba z 02.04.1980, Teatr Śmierci, s. 309).

Nadal nie jestem zadowolony z przebiegu tej sceny, ustalonej na poprzednich próbach (Wielopole, Wielopole, scena „Ostatnia Wieczerza”, próba z 08.05.1980, Teatr Śmierci, s. 314).

Zmieniam cały plan dość radykalnie. W czasie tej samej próby. Jeszcze raz przekonuję się, że mój charakter pracy wyklucza pisanie „partytury” przed próbą (Wielopole, Wielopole, scena „Ostatnia Wieczerza”, próba z 08.05.1980, Teatr Śmierci, s. 317).

Wprawdzie ustaliłem, że ostatnia wersja „Ostatniej Wieczerzy” jest ostateczna, jednak pozostawiam jeszcze wolne pole wyobraźni. Wcale nie mam zamiaru robić próby „Ostatniej Wieczerzy”. Chcę jedynie sprawdzić stół, (który) miał się

31 Strategia inscenizowania, unaoczniania procesu tworzenia przypomina Derridiańskie inscenizacje tekstualne. Zob. A. Burzyńska, Dekonstrukcja i interpretacja, Kraków 2001, s. 53 i n. 
okazać stołem dopiero na końcu. (...) Pozostają dwie nagie deski. Zastanawiam się, co z nimi zrobić. (...) Ale nie jestem spokojny. Pragnę sobie wyobrazić inne rozwiązanie STOŁU (Wielopole, Wielopole, scena „Ostatnia Wieczerza”, próba z 30.05.1980, Teatr Śmierci, s. 320) ${ }^{32}$.

Równoległe prowadzenie obserwacji narodzin dzieła i towarzyszących temu własnych procesów myślowych pozwala mówić o pisaniu biografii dzieła i biografii twórcy jednocześnie ${ }^{33}$.

Można powiedzieć, że to świadomość artysty sama staje się zasadniczą materią dzieła, a w tejże materii ustanawia się też wciąż na nowo artystyczna tożsamość twórcy. Daje się ona opisywać w kategoriach zbierania i rozproszenia ${ }^{34}$, zyskuje dramatyczny, performatywny wymiar ${ }^{35}$.

Rację ma Giovanni Raboni, gdy stwierdza:

Kantor nie wystawia cudzych tekstów, ani nawet tekstów własnych - wystawia samego siebie. Siebie samego, to znaczy własną przeszłość, własne wspomnienia i myśli, własną śmierć... ${ }^{36}$.

Tak jak świadomość będąca tworzywem sztuki twórcy Umartej klasy nie daje się opisywać w kategoriach skończoności, całości, doskonałości, tak nie daje się $\mathrm{w}$ ten sposób mówić również o dziele artysty. Jedynie trafna wydaje się tu Kantorowska kategoria NIEMOŻLIWEGO.

Nobilituje się więc to, co niepełne, nieskrystalizowane, chwiejne, ciągle ruchome i nieukończone, co daje się widzieć jako przymiarka, próba, a czego jednak ostatecznie nie udaje się ogarnąć.

Pozostawić PRÓBY i tylko PRÓBY! Jak zwykle próby często nieuda$n e, z$ błędami, $z$ poprawkami, zmianami, wariantami, powtarzaniem ${ }^{37}-$ postulował Kantor.

To myślenie wywiedzione przecież z prób spektakli z powodzeniem można przenieść na teksty autora Umarłej klasy.

32 Opuszczenia w cytowanym fragmencie moje - I.G.

${ }^{33}$ Analogiczne działanie proponuje T. Różewicz w Przyroście naturalnym.

34 Zob. A. Kunce, Tożsamość i postmodernizm, Warszawa 2003. Autorka zauważa, że metafora zbieranie odsyła do myślenia o scalaniu tożsamości z różnych napotkanych fragmentów kontekstów, strzępów różnych rzeczywistości, odsuwa na dalszy plan myślenie o tożsamości gotowej „danej z góry” (s. 45). Rozproszenie zaś wskazuje na „permanentny stan braku scalenia”. To trop, „który ma pomóc w opisie tożsamości jako »dziania się«" (s. 47).

$35 \mathrm{Na}$ temat tożsamości performatywnej zob. W. Welsch, Stając się soba, przeł. J. Wietecki, [w:] Problemy ponowoczesnej pluralizacji kultury. Wokót koncepcji Wolfganga Welscha, red. A. Zeidler-Janiszewska, Poznań 1998. Por. też: E. Partyga, Tożsamość dziś: narracyjna? dialogowa? performatywna?, „Przestrzenie Teorii” 2008, nr 10.

36 Cyt. za: K. Pleśniarowicz, Dzieło $i$ komentarz Kantora - przenikanie granic, [w:] T. Kantor, Dalej już nic..., dz. cyt., s. 468.

${ }^{37}$ T. Kantor, Iluzja i powtarzanie, [w:] tegoż, Wielopole, Wielopole, Wrocław 1984, s. 17.

Irena Górska


Zapisy prób dają się czytać jako korekcje, powtórzenia, bo w próby wpisana jest powtarzalność. Próbuje się po to, aby wychwycić błędy, niedoskonałości, a następnie je wyeliminować. Zatem powtarza się to samo i nie to samo jednocześnie. W każde powtórzenie wpisana jest różnica ${ }^{38}$.

Jednak swoistość sporządzanych przez Kantora notatek z prób tkwi przede wszystkim w tym, że stanowią one formę odgrywania aktu odgrywania. To, co zostało odegrane na scenie, raz jeszcze zostaje odegrane - mówiąc po Różewiczowsku - „na papierze”.

Można powiedzieć, że zapiski z prób, będące często wielokrotnym rozpisywaniem tej samej sceny, to performatywna gra, ustanawianie na oczach widzów wciąż nowych wersji. Pojawia się jednak wątpliwość: czy chodzi o wersję sceny w spektaklu, czy wersję notatki?

Analizujemy przecież nie same próby, lecz notatki z prób. Choć fakt ten wydaje się oczywisty, to każe postawić jeszcze jedną niezwykle istotną kwestię. Na ile te zapisy są spontanicznym odzwierciedleniem tego, co działo się podczas danej próby na scenie, a na ile opracowanym literacko tekstem. Może z prób spektakli powstają po prostu próby literackie? Takie myślenie uprawomocnia fakt, że Kantor dokonywał nie tylko korekt prób scenicznych, ale też notatek z tychże prób.

Znamiennym przykładem jest Korekta korekty. Jest to bowiem nie tylko refleksja nad ostatnią próbą spektaklu Wielopole Wielopole, ale też nad dokonanymi po niej zapiskami.

Przeglądam na świeżo notatki z ostatniej próby.

Nie podobają mi się $e^{39}$.

Co istotne, nawet Korekta korekty pcha artystę ku obszarom poetyckim:

Dystans

Nieruchomość

Jak upozowanie na zdjęciu skierowane „ku wieczności”.

To upozowanie „ku wieczności” jest przerażające.

Jest przeczuciem śmierci.

Widmo.

Upiorna nieruchomość. -

Obcość. Jak we śnie.

Sen. Nierealność.

Tajemniczość! 40

38 Zob. G. Deleuze, Różnica i powtórzenie, przeł. B. Banasiak, K. Matuszewski, Warszawa 1997.

39 T. Kantor, Teatr Śmierci..., dz. cyt., s. 297.

40 Tamże, s. 298. 
Chęć poprawiania spektaklu (?), notatki o nim (?) zamienia się w wiersz. Jeszcze inaczej można powiedzieć, że z próby spektaklu rodzi się próba poezji.

\section{Partytury, czyli projektowanie dramatu}

Szczególną odmianę pisarstwa Kantora stanowią partytury. Odsyłając do myślenia opozycjami: literatura i komentarz, centrum i margines, pisanie i czytanie, jednocześnie te opozycje znoszą.

Kantor wyznaje:

Obowiązek wystawienia sztuki wydaje mi się śmieszny i nudny. Tekst autora potrzebny mi jest tylko jako drabina. Po niej wspinam się, bo mam ważniejsze sprawy do załatwienia ${ }^{41}$.

Zatem dramaty Słowackiego, Wyspiańskiego, a przede wszystkim Witkacego stanowią dla Kantora punkt wyjścia do pracy nad spektaklem, ale - można przewrotnie powiedzieć - że sa też punktem dojścia. Od aktu lektury dramatu zmierza Kantor na scenę, do spektaklu, by następnie dojść do aktu pisania partytury. Pisanie to dokonuje się na scenie w czasie prób:

To właśnie próba, spontaniczne i gwałtowne decyzje, pomysły i działania są „pisaniem” partytury. Potem należy tylko dokonać zapisu (Wielopole, Wielopole, scena „Ostatnia Wieczerza”, próba z 08.05.1980, Teatr Śmierci, s. 317).

Zaczyna więc Kantor od tekstu dramatu, wypróbowuje go na scenie już we własnym przetworzeniu, by ponownie powrócić do tekstu już odegranego i przetworzonego. $\mathrm{Na}$ tym etapie dochodzi do pisania własnego tekstu, który jest komentarzem i do wyjściowego dramatu, i do spektaklu, ale jest też próbą literacką.

Na podstawie dramatów Słowackiego, Wyspiańskiego czy Witkacego Kantor pisze partytury dramatów, ale to nie są projekty wykonania jego spektakli tak jak w klasycznym rozumieniu partytury będącej zapisem wszystkich głosów i instrumentów niezbędnych do wykonania danego utworu. Partytury Kantora powstawały zawsze dopiero po wystawieniu spektakli.

Nie sa to więc reżyserskie scenariusze, bo nie stużyty pracy nad przedstawieniami, ani postzapisy - z braku walorów dokumentacyjnych - odnotowuje K. Pleśniarowicz ${ }^{42}$.

${ }^{42}$ K. Pleśniarowicz, Dzieło i komentarz Kantora - przenikanie granic, dz. cyt., s. 454.

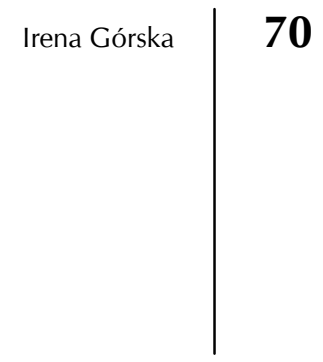


Jeśli przyjąć, że sam dramat już w pewnym sensie jest sceniczną partyturą, można powiedzieć, że Kantor pisze partyturę partytury. $\mathrm{W}$ partyturowym zapisie projektuje spektakl, jednak nie ten już wystawiony, lecz potencjalny, który dopiero mógłby powstać. Zatem ze spektaklu rodzi się tekst literacki, a może kolejna wersja dramatu Słowackiego, Wyspiańskiego lub Witkacego czy wreszcie pomysł na jeszcze inny spektakl? W jakimś sensie to Kantor, tworząc partyturę, pisze wersje wybranego dramatu, a może raczej projektuje własny tekst dramatyczny? Wbrew temu, że partytury Kantora miały być ucieczką od dramatyczności, która tylko łudzi możliwością bezpośredniego przedstawiania, to właśnie dramatycznie nacechowane są tu słowa, które tworzą sytuacje i zdarzenia, unaoczniają je, a nie relacjonują ${ }^{43}$.

Zdaniem Kantora Tworzenie „form scenicznych” jest równoznaczne $z$ "pokazywaniem” utworu dramatycznego ${ }^{44}$. Parafrazując te słowa, można powiedzieć, że tworzenie partytur jest równoznaczne $\mathrm{z}$ pokazywaniem spektaklu, rozgrywaniem go raz jeszcze $\mathrm{w}$ formie literackiej.

W partyturze rozumianej jako zapis nutowy głosy poszczególnych instrumentów notowane są w sposób symultaniczny jeden nad drugim. Kantor często też taki symultaniczny zapis stosuje, z tym że omawiany, streszczany tekst dramatu i własną partyturę zapisuje w kolumnach obok siebie. Równoległy w wymiarze wizualnym zapis uprawomocnia myślenie o marginesach i zapisywanych na nich glosach, a także o dramatycznej grze pomiędzy dramatem i jego partyturą. Sprawę komplikuje fakt, że kolumny tekstu przecinane są czasem poprzecznie przez uwagi $z$ notatnika reżysera. Te zaś odsyłają do myślenia o tekście głównym i pobocznym, w sposób dosłowny wskazują też na obecność twórcy, reżysera na scenie. Silna wizualność partytur każe je nie tylko czytać, ale też oglądać.

Można powiedzieć, że partytura w wydaniu Kantora jest opisem, komentarzem do dramatu i do teatru. Ma charakter liminalny ${ }^{45}$, sytuuje się bowiem w obszarze „pomiędzy”, na marginesie; nie jest wierna ani dramatowi (bo tylko luźno się do niego odwołuje), ale też nie musi być wierna scenicznej realizacji (jest raczej literacką wersją odegranego już spektaklu). Wykorzystuje dramat, by prowadzić z nim grę.

Partytury, przewodniki po spektaklach, notatki, zapisy prób splatają dramat, komentarz, teatr, autorskie refleksje teoretyczne i biograficzne,

${ }^{43}$ Zob. uwagi K. Pleśniarowicza na temat partytury Kurki Wodnej, [w:] tegoż, Dzieło $i$ komentarz Kantora - przenikanie granic, dz. cyt., s. 455.

44 T. Kantor, Metamorfozy..., dz. cyt., s. 78.

45 Zob. E. Fischer-Lichte, Liminalność i przemiana, [w:] taż, Estetyka performatywności, przeł. M. Borowski, M. Sugiera, Kraków 2008. 
obserwacje dzieła i stanów własnej świadomości. Wszystko to wytwarza dramatyczne napięcie pomiędzy teatrem a pisarstwem, teorią a praktyką artystyczną, twórcą a jego dziełem. Teksty wyrastające z myślenia o teatrze, z realizacji teatralnych idei zyskują rys dramatyczny. Balansują nieustannie na granicy między teorią a literaturą. Stają się sceną, na której wypróbowuje się raz jeszcze to, co rozegrane już było w teatrze. Można powiedzieć, że w swoim pisarstwie odtwarza artysta z Wielopola własny teatr i własną biografię:

Pisane przez całe życie manifesty i autokomentarze Tadeusza Kantora dyktowało dążenie do kreowania i odtwarzania wciąż na nowo własnej artystycznej biografii. By wszystko skorygować, dopełnić, poprawić ${ }^{46}$.

Temu odtwarzaniu i korygowaniu własnej biografii towarzyszy jednocześnie pisanie biografii własnego dzieła literackiego (nawet jeśli dzieło to powstawało niejako poza świadomością artysty i mimowolnie zostało wpisane w teksty teoretyczne).

Nie wydaje się dziś chyba nadużyciem czytanie tekstów teoretycznych Kantora jako literatury. Nie chodzi jednak tylko o uchwycenie literackiego, poetyckiego charakteru tekstów teoretycznych autora Umarłej klasy, ale o pokazanie, że projekt teatralny jest próbą projektu literackiego, że to teatr projektuje literaturę. Mówiąc jeszcze inaczej - twórczość Kantora dowodzi, że - odwrotnie niż u Różewicza - z zamysłu teatralnego rodzi się literatura. Na przeciwległym biegunie biografii sztuki teatralnej autora Przyrostu naturalnego odnaleźć można biografię sztuki literackiej twórcy Umarłej klasy.

Witkacy w swoich szkicach estetycznych daje próbki literatury, w dramatach rozgrywa teorie własne i cudze ${ }^{47}$, Różewicz teksty teoretyczne „każe” czytać jako dramat lub prozę (sposób lektury często podpowiada tytuł zbioru), ale też np. zamienia opowiadanie w traktat estetyczny (np. Grzech). Kantor natomiast szkic estetyczny, komentarz teoretyczny, manifest niejednokrotnie zamienia w literaturę.

Gdy zainscenizowany już został Witkacowski akt lektury i odegrany Różewiczowski akt pisania, pora, by raz jeszcze odegrany został sam akt odgrywania. To tautologiczne określenie ma wskazywać nie tylko na przywołany już uprzednio fakt ponownego rozgrywania, przede wszystkim w tekstach partytur Kantora, odegranych już spektakli, ale też na całość pisarstwa, w którym odgrywa się teatralne idee.

Odgrywanie aktu odgrywania daje się widzieć jeszcze inaczej, a mianowicie w perspektywie performatywnej gry prowadzonej nieustannie

${ }^{46}$ K. Pleśniarowicz, Nota od wydawcy, [w:] T. Kantor, Metamorfozy ..., dz. cyt., s. 5.

47 Zob. A. Krajewska, Witkacego inscenizacje tekstualne, „Pamiętnik Literacki” 2002, z. 4.

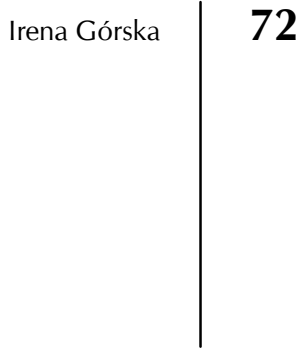


między ideami teatralnymi zrealizowanymi we własnym teatrze, a pisanymi tekstami, które są zapewne w jakimś stopniu narzędziem kreowania artystycznej biografii. Kantor rozgrywa pomysły teatralne na scenie, ale też w obrębie tekstów teoretycznych; opisuje próby, które już się odbyły, komentuje je, wyraża własne wątpliwości, koryguje same próby sceniczne, ale też notatki z prób, pisze korekty i korekty korekt. Można powiedzieć, że w ten sposób prowadzi do ustanawiania wciąż na nowo relacji między własnym teatrem i literaturą.

Pisarskie formy, które uprawia Kantor, charakteryzuje pewna dwoistość. Fakt, że wyrastają one z myślenia o teatrze, sprzyja unaocznianiu procesu twórczego obejmującego zarówno obszar teatru, jak i literatury. Pola te nieustannie się ścierają i uzupełniają. Odegrane spektakle stanowią impuls do spisywania własnych idei teatralnych, pisanie niesie więc informację o samym akcie pisania, ale i o akcie odgrywania spektaklu w teatrze (osobną kwestią jest fakt, na ile te opisy są wierne przedstawieniom).

O ile Różewicz i Witkacy we własnym pisarstwie projektują dramat / teatr, to Kantor w teatrze zaprojektował własne pisarstwo. Jego teksty teoretyczne grają dramatycznie, a nawet teatralnie, jako projekt literacki. 
